\title{
Evaluation of Air Stripping Process for Ammonia Removal from Landfill Leachate
}

\section{Leite VD*, Oliveira EGD, Costa EFM, Dantas GD and Araujo ECOD}

State University of Paraiba, Brazil

*Corresponding author: Valderi Duarte Leite, State University of ParaibaCCT/DESA/PPGCTA- Campina Grande (PB)-Brazil. Tel: (+55) 83-33109705; E:mail:

\section{Research Article \\ Volume 1 Issue 2}

Received Date: October 01, 2018

Published Date: October 20, 2018

DOI: $10.23880 /$ oajwx-16000108 mangabeiraleite@gmail.com

\section{Abstract}

Of the amount of urban solid waste collected in Brazil, 58.4\% (percentage by weight) had an adequate destination, while $41.6 \%$ were sent to landfills or controlled landfills. The leachate is one of the main by - products derived from the landfill process of municipal solid waste in landfills and presents qualitative/ quantitative characteristics with significant polluting potential, since it has a high concentration of recalcitrant organic material, a high concentration of ammoniacal nitrogen, a significant concentration of certain heavy metals and xenobiotic organic and inorganic compounds. The air stripping process of ammoniacal nitrogen presents as a viable alternative for reducing the concentration of ammoniacal nitrogen from landfill leachate, in order to facilitate the transfer of mass from the liquid phase to the gaseous phase. The objective of the application of the ammonia air stripping process in landfill leachate is to reduce the concentration of ammoniacal nitrogen to desired levels in systems optimized for operational parameters, especially pH. The experimental tests were performed on Jar Test apparatus, and two $\mathrm{pH}$ levels were studied. The application of the air stripping process to reduce the concentration of ammoniacal nitrogen in the landfill leachate showed removal efficiency of $87.0 \%$ in experiment 1 and $97.0 \%$ in experiment 2 , for a time of operation the reactors of 4.1 day.

Keywords: Urban Solid Waste; Landfill Leachate; Ammonium Air Stripping

\section{Introduction}

In developing countries and with great availability of territorial space, as is the case in Brazil, the most suitable technique for the final disposal of urban solid waste (USW) is, to date, the landfill. The main advantage of implementing this type of system would be the low cost in relation to other treatment techniques and / or final destination [1,2]. In Brazil, about 168 thousand tons of urban solid waste is produced daily. Of this amount, about 35 thousand tons are destined to landfill, which generates as by-products biogas and leachate from landfill [3]. Of the solid urban waste generated by the Brazilian population, about 50\% (percentage by weight) is putrescible organic matter of different chemical composition and it is this organic matter that is 
responsible for the high concentration of carbonaceous material in the leachate. On the other hand, a significant fraction of xenobiotic material can be found within the matrix of Brazilian urban solid waste, especially from paints, varnishes, lubricating oils, herbicides, pesticides, defoliants, as well as an expressive range of heavy metals.

The landfill leachate is formed from the natural moisture of the grounded municipal waste, the infiltrated water in the landfill, and the products of the biological degradation of the organic matter fraction of the urban solid waste [4]. In general, it presents high organic load, high concentration of ammoniacal nitrogen and may contain heavy metals and aromatic hydrocarbons, which provide a certain degree of toxicity. If the leachate is not treated properly, it can cause serious environmental impacts, such as acceleration of the eutrophication process, contamination of soils and groundwater. Thus, it is found that the treatment of leachate produced in landfills is of utmost importance to the maintenance of environmental quality and public health.

According to Salem, et al. the chemical composition of landfill leachates is variable depending on the type and stage of USW decomposition, degree of stability of municipal solid waste, local hydrology, seasonal climatic variation, moisture content of solid wastes and the age of the landfill [5].

The amount of leachate generated in a sanitary landfill depends primarily on the percolation of rainwater that possibly infiltrates the cells of the solidified municipal solid waste, the biochemical processes that occur in the bio-stabilization of the organic matter, the percentage of moisture of the urban solid waste and the degree of compaction of the residues in the landfill [6]. In Brazil, the percentage of TKN present in USW is approximately $1 \%$ on a dry basis (percentage by weight) and of this quantitative, about $91.0 \%$ is ammoniacal nitrogen. Therefore, the expressive percentage of ammoniacal nitrogen present in the grounded USW, associated to the fraction of organic nitrogen that will be ammoniated, will result in a significant concentration of ammoniacal nitrogen in the leachate generated by the sanitary landfills.

In water resources, ammonia in its non-ionized form $\left(\mathrm{NH}_{3}\right)$ can be toxic to several organisms, affecting the growth rate, or even compromising the quality of these water resources due to eutrophication, caused by excess ammonia together with phosphorus. Therefore, the leachate produced and collected in landfills requires treatment before its release into the environment.
According to Resolution 430/2011 of the National Environmental Council (CONAMA), the maximum allowed release concentration for ammoniacal nitrogen is $20 \mathrm{mg} /$ L [7]. As for human health, the effects caused by contact with ammonia vary according to the intensity and the time of exposure. For mild and moderate exposures and concentrations between 40 and $700 \mathrm{mg} / \mathrm{L}$, irritation of the respiratory tract, lungs and eyes, nausea, sore throat and head can be caused. More severe exposures may cause hemoptysis, bronchospasm, pulmonary edema, severe burns to the skin and eyes and in cases of exposures greater than $5000 \mathrm{mg} / \mathrm{L}$, contact may be lethal $[8,9]$. The concentrations of ammoniacal nitrogen from landfill leachate in the three different samples ranged from $2,450.0$ to $2,550.0 \mathrm{mgN} / \mathrm{L}$ and this magnitude of concentration already generates serious human health problems, such as irritation in the respiratory tract lungs and eyes, nausea, sore throat and headaches. When it comes to concentration above $700 \mathrm{mgN} / \mathrm{L}$ more serious problems may occur, including bronchospasm, pulmonary edema and severe burns in the skin and eyes. Therefore, taking into account the quantitative aspects of ammoniacal nitrogen generation through various human and industrial activities, it will be necessary to take care of the release of ammonia gas, given its strong impacts on my environment and human health.

According to Metcalf \& Eddy, air stripping consists of a physical process that relies on the mass transfer of a volatile undesirable compound, from the liquid phase to the gas phase through the injection of air which is passed through the liquid medium, by means of aeration mechanisms. The mass transfer from the liquid phase to the gaseous phase is called the technical desorption, although the term most commonly used in sanitary and environmental engineering isair stripping.

During the air stripping process, carbonates and bicarbonates may form in the filling material and may cause mass transfer. Temperature, $\mathrm{pH}$, air flow, volumetric charge and reactor configuration are among the parameters that most affect the efficiency of ammonia removal $[10,11]$.

The removal of ammoniacal nitrogen through the air stripping process with air injection consists in raising the $\mathrm{pH}$ of the leachate to values around of 12 , in order to propitiate the conversion of the ammonium ion to ammonia gas. This alkalinization of the medium is carried out prior to air stripping, generally by the addition of sodium hydroxide or calcium hydroxide. The term ammoniacal nitrogen is used to denote the nitrogen species in ionic form $\left(\mathrm{NH}_{4}{ }^{+}\right)$and molecular $\left(\mathrm{NH}_{3}\right)$, depending on the $\mathrm{pH}$ of the solution. In aqueous medium 
and $\mathrm{pH}$ around of 7 , the ammoniacal nitrogen is in equilibrium in two forms, which are the ionic $\left(\mathrm{NH}_{4}{ }^{+}\right)$and the molecular gas $\left(\mathrm{NH}_{3}\right)$. The equilibrium equation between these two species is presented in Equation 1 [10].

$$
\mathrm{NH}_{3(\mathrm{~g})}+\mathrm{H}_{2} \mathrm{O}_{(\mathrm{l})} \leftrightarrow \mathrm{NH}_{4}^{+}{ }_{(\mathrm{aq})}+\mathrm{OH}^{-}{ }_{(\mathrm{aq})}
$$

The equilibrium of this equation depends on some factors, mainly $\mathrm{pH}$ and temperature. Therefore, the higher the $\mathrm{pH}$, the higher the percentage of $\mathrm{NH}_{3}$ in the wastewater. For, Equation 1 moves to the left and the ammonium ion $\left(\mathrm{NH}_{4}{ }^{+}\right)$converts to ammonia gas $\left(\mathrm{NH}_{3}\right)$. Based on Equation 1 and assuming the value of the dissociation constant $(\mathrm{Kb})$ at $25^{\circ} \mathrm{C}$ equal to $1.8 \times 10^{-5}$, the dissociation constant can be quantified by applying Equation 2.

$$
\mathrm{K}_{\mathrm{b}}=\frac{\left[\mathrm{NH}_{4}^{+}\right] \times\left[\mathrm{OH}^{-}\right]}{\left[\mathrm{NH}_{3}\right]}
$$

At where,

$\mathrm{K}_{\mathrm{b}}$ :Basicity dissociation constant;

$\mathrm{NH}_{4}{ }^{+}$: Concentration of the ammonium ion (mol/L);

$\mathrm{OH}:$ Concentration of the hydroxyl ion $(\mathrm{mol} / \mathrm{L})$;

$\mathrm{NH}_{3}$ : Concentration of ammonia gas (mol/L).

Using the dissociation constants of water and base, equation 2 will now be represented by equations 3 and 4 .

$$
\alpha_{N H_{4}^{+}}=\frac{k_{b} \times H^{+}}{k_{b} \times H^{+}+k_{w}}
$$

and

$$
\alpha_{N H_{2}}=\frac{k_{w}}{k_{b} \times H^{+}+k_{w}}
$$

At where:

$\alpha_{\mathrm{NH}_{4}^{+}}$: Fraction of the ammonium ion;

$\alpha_{\mathrm{NH}_{2}}$ : Fraction of ammonia gas;

$\mathrm{K}_{\mathrm{b}}$ : Base dissociation constant;

$\mathrm{H}^{+}$: Concentration of the hydrogen ion $\left(\mathrm{mol} . \mathrm{L}^{-1}\right)$;

$\mathrm{K}_{\mathrm{W}}$ : Water dissociation constant.

\section{Material and Methods}

For the accomplishment of the experimental work, three different samples of leachate were collected in the sanitary landfill of the city of João Pessoa, state of Paraíba, northeast region of Brazil. The leachate was transported to the Basic Sanitation Laboratory of the UEPB Sanitary Sewage Treatment Station (EXTRABES), submitted to a physicochemical and preserved characterization. The experiments of the ammonia stripping process were performed on Jar Test equipment, as shown in Figure 1 and the ambient temperature (Tables $1 \& 2$ ).

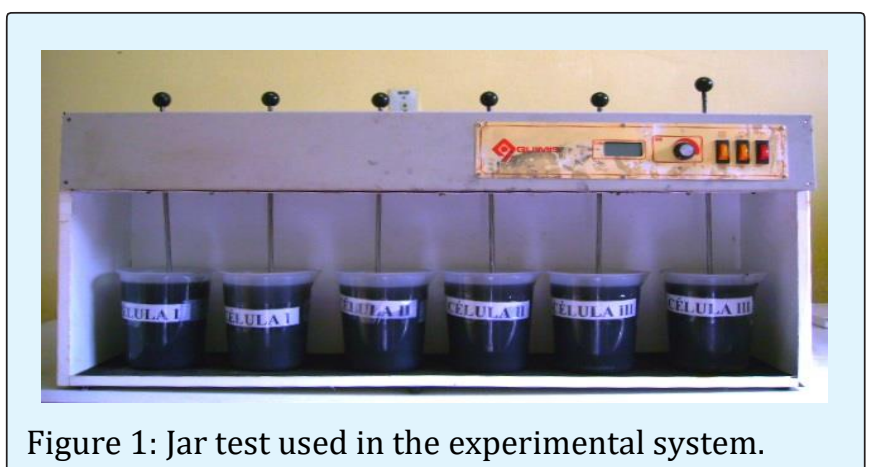

Tables 1 \& 2 show the operational data applied for experiments 1 and 2 .

\begin{tabular}{|c|c|c|c|c|c|c|}
\hline Parameters & $\mathbf{V}_{\mathbf{R}}$ (L) & $\mathbf{V}_{\mathbf{L}}$ (L) & $\mathbf{V}_{\mathbf{R}}$ (RPM) & $\begin{array}{c}\mathbf{t} \\
\text { (hours) }\end{array}$ & $\begin{array}{c}\mathbf{F}_{\mathbf{C}} \\
\text { (hours) }\end{array}$ & $\mathbf{p H}$ \\
\hline Magnitude & 1.2 & 1.0 & 90.0 & 100.0 & 8.0 & 8.0 \\
\hline
\end{tabular}

Table 1: Operational parameters applied to perform experiment 1 .

$\mathrm{V}_{\mathrm{R}}$ : Reactor volume; $\mathrm{V}_{\mathrm{R}}$ : Leachate volume; $\mathrm{V}_{\mathrm{R}}$ : Rotational Speed; t: Time (hours); $F_{C}$ : Frequency of collection.

\begin{tabular}{|c|c|c|c|c|c|c|}
\hline Parameters & $\mathbf{V}_{\mathbf{R}}(\mathbf{L})$ & $\mathbf{V}_{\mathbf{L}}(\mathbf{L}) \mathbf{V}_{\mathbf{R}}$ (RPM) & $\begin{array}{c}\mathbf{t} \\
\text { (hours) }\end{array}$ & $\begin{array}{c}\mathbf{F}_{\mathbf{C}} \\
\text { (hours) }\end{array}$ & $\mathbf{p H}$ \\
\hline Magnitude & 1.2 & 1.0 & 90.0 & 100.0 & 8.0 & 9.0 \\
\hline
\end{tabular}

Table 2: Operational parameters applied to perform experiment 2.

$\mathrm{V}_{\mathrm{R}}$ : Reactor volume; $\mathrm{V}_{\mathrm{R}}$ : Leachate volume; $\mathrm{V}_{\mathrm{R}}$ : Rotational Speed; t: Time (hours); $F_{C}$ : Frequency of collection.

The analytical parameters monitored were $\mathrm{pH}$ and total alkalinity, taking into account the recommendations of APHA [12].

\section{Results and Discussion}

Table 3 shows the data coming from the physical and chemical characterization of the three different samples of leachate collected from the landfill to perform the experiments. 


\section{Open Access Journal of Waste Management \& Xenobiotics}

\begin{tabular}{|c|c|c|c|}
\hline Score $/$ parametre & Score 1 & Score 2 & Score 3 \\
\hline $\mathrm{pH}$ & 8 & 8.5 & 7.5 \\
\hline Total alcalinity $\left(\mathrm{mgCaCO}_{3} / \mathrm{L}\right)$ & $10,500.00$ & 14,200 & $12,558.00$ \\
\hline${\text { Volateli fatty acids }\left(\mathrm{mgH}_{\mathrm{AC}} / \mathrm{L}\right)}_{\left.4 \mathrm{COD}_{2} / \mathrm{L}\right)}^{422,4}$ & 576,0 & 840 \\
\hline $\mathrm{COD}_{\text {soluble }}\left(\mathrm{mgO}_{2} / \mathrm{L}\right)$ & $20,180.00$ & $18,513.00$ & $23,100.00$ \\
\hline Total phosphorus(mg/L) & $6,600.00$ & $5,200.00$ & $7,950.00$ \\
\hline Soluble phosphorus (mg/L) & 11 & 9.3 & 12.7 \\
\hline TKN (mg/L) & 6 & 5.9 & 6.9 \\
\hline Amoniacal nitrogen $(\mathrm{mg} / \mathrm{L})$ & $2,490.00$ & $2,440.00$ & $2,520.00$ \\
\hline TS (mg/L) & $2,290.00$ & $2,390.00$ & $2,282.00$ \\
\hline FTS (mg/L) & $22,100.00$ & $20,800.00$ & $25.100,0$ \\
\hline VTS (mg/L) & $15,500.00$ & $15,600.00$ & $15,150.00$ \\
\hline TSS (mg/L) & $6,600.00$ & $5,200.00$ & $7,950.00$ \\
\hline FSS (mg/L) & 981 & 927 & $1,035.00$ \\
\hline VSS (mg/L) & 122 & 188 & $1,692.00$ \\
\hline
\end{tabular}

Table 3: Data from the chemical characterization of the three different samples of landfill leachate.

Analyzing the data from the chemical characterization of the landfill leachate in the city of João Pessoa, it can be verified that the $\mathrm{pH}$ ranged from 7.5 to 8.5 , which means that the percentage of non - ionized ammoniacal nitrogen is varying from 97 to $76 \%$ respectively, for $\mathrm{pH}$ magnitudes ranging from 7.5 to 8.5 . The carbonaceous material, expressed in terms of total COD, ranged from 18, 513.0 to $23,100.0 \mathrm{mgO}_{2} / \mathrm{L}$. However, from the total COD concentration, on average $32.8 \%$ corresponds to the soluble COD concentration, which means that there is presence of difficult biodegradable material and with intrinsic characteristics of xenobiotic materials.

The leachate has a significant concentration of total alkalinity, ranging from $10,500.0$ to $14,200.0 \mathrm{mgCaCO}_{3} / \mathrm{L}$ and volatile fatty acid concentration ranging from 422.40 to $840.0 \mathrm{mgH}_{\mathrm{AC}} / \mathrm{L}$. The concentration of total solids varied from $20,800.0$ to $25,100.0 \mathrm{mgTS} / \mathrm{L}$ and of this concentration, the most significant percentage is in the form of dissolved solids (Figure 2).

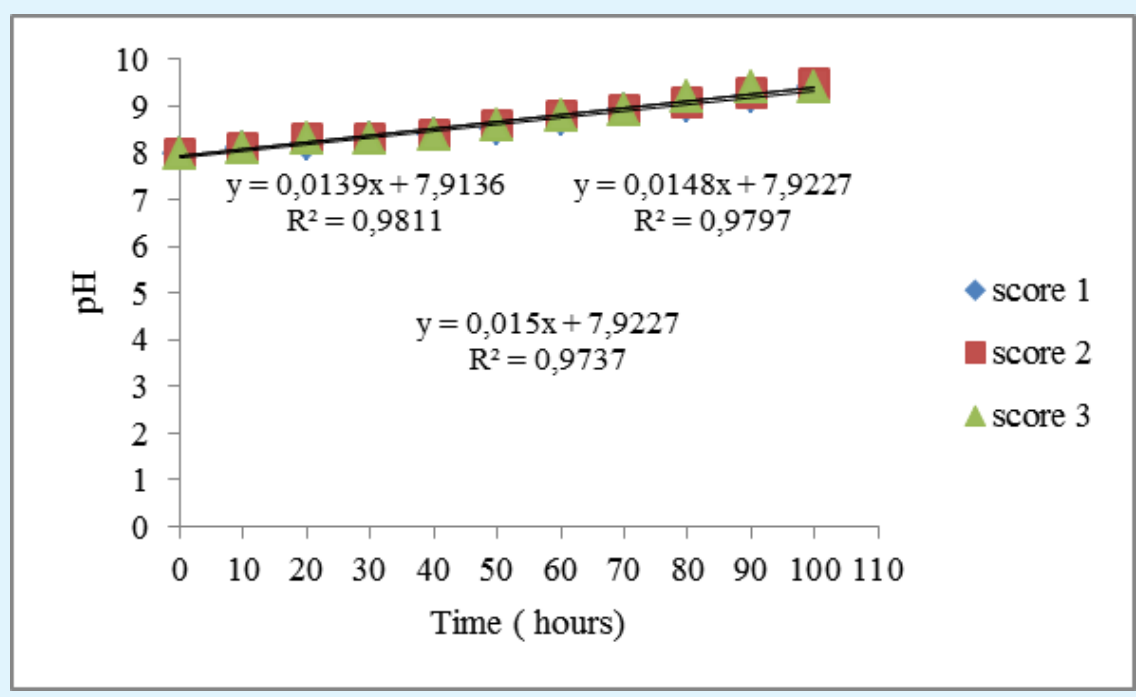

Figure 2: Shows the behavior of the time variation of the $\mathrm{pH}$ of the leachate in the ammonia air stripping process in experiment 1. 
Analyzing the behavior of temporal variations of $\mathrm{pH}$, an incremental increase can be observed over the monitoring period. This phenomenon can be explained by the entrainment of certain chemical species of the medium with slightly acidic characteristics and, on the other hand, the high concentration of total alkalinity already present in the medium, that in magnitudes of $\mathrm{pH}$ up to 10 is this nartural tendency. The progressive addition of $\mathrm{pH}$ contributes substantially to the conversion of the $\mathrm{NH}^{4+}$ ion to ammonia gas (Equation 1) and the consequent release of the liquid medium. In this experiment, the initial $\mathrm{pH}$ of the three different types of leachate was adjusted to eight and at the end of the monitoring period, which was 100 days, the $\mathrm{pH}$ ranged from 9.4 to 9.5 , favoring conditions more favorable to the release of the gas ammonia.

The behavior of the temporal variation of the $\mathrm{pH}$ of the landfill leachate in an ammonia stripping process is presented in Figure 3.

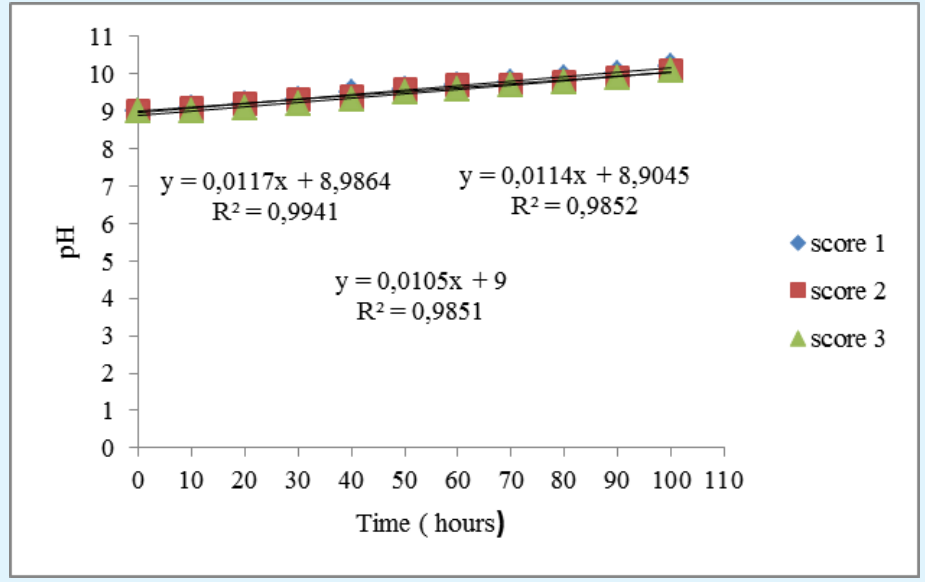

Figure 3: Behavior of temporal variation of $\mathrm{pH}$ in experiment 2.

In relation to experiment 2 , the initial $\mathrm{pH}$ of the three different samples of leachate was adjusted to nine $\mathrm{pH}$ units and was increased progressively, reaching the level of $10.2 \mathrm{pH}$ units. For this $\mathrm{pH}$ level, of the concentration of ammoniacal nitrogen, fraction higher than $84.7 \%$ is in the no ionized form, facilitating the process of ammonia air stripping. In Figure 4, the behavior of the temporal variations of the ammoniacal nitrogen concentrations of the landfill leachate in the ammonia airstripping process in experiment 1 (Figure 4).

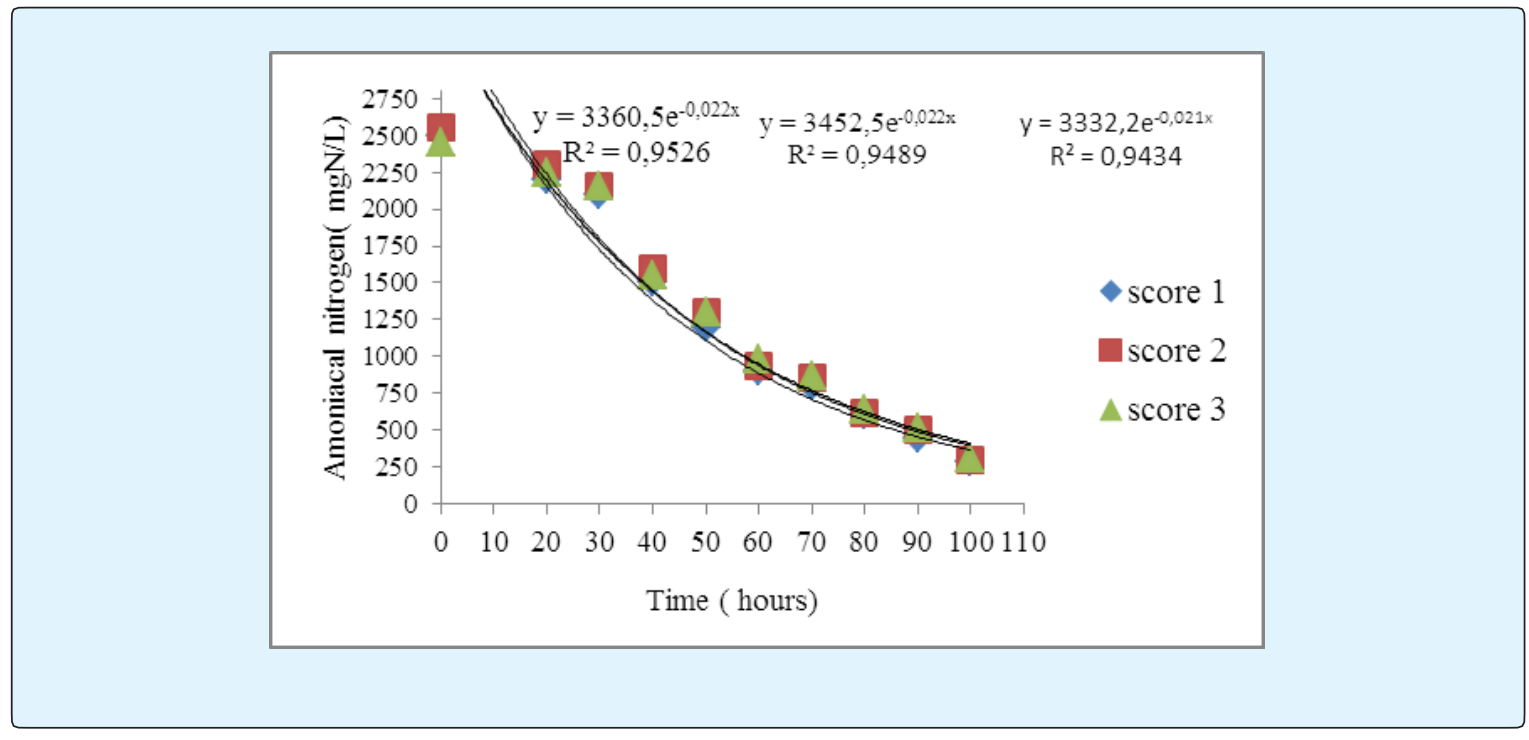

Leite VD, et al. Evaluation of Air Stripping Process for Ammonia Removal from Landfill Leachate. J Waste Manage Xenobio 2018, 1(2): 000108. 


\section{Open Access Journal of Waste Management \& Xenobiotics}

Figure 4: Behavior of temporal variations of ammoniacal nitrogen concentrations in experiment 1.

The ammonia air stripping process emerges as a promising technological alternative for the removal of ammonia gas from any liquid residue and its consequent use as a chemical fertilizer. In this experiment, the ammonia air stripping process was studied at a $\mathrm{pH}$ equal to $8.0 \mathrm{pH}$ units, which is why the objective was to verify how long it would be necessary at this $\mathrm{pH}$ level for the concentration of ammoniacal nitrogen to be reduced to an acceptable level for effluent treatment via biological process. The mean reduction of the ammoniacal nitrogen concentration was $88.0 \%$, for a monitoring period of 100 hours. Since no chemical species was used to raise the $\mathrm{pH}$, the costs associated with the air stripping process in its entirety are associated with the consumption of electric energy consumed by the Jar Test apparatus.

In Experiment 2, the behavior of the temporal variations of ammoniacal nitrogen concentrations of landfill leachate in the ammoniaair stripping process are presented in Figure 5.

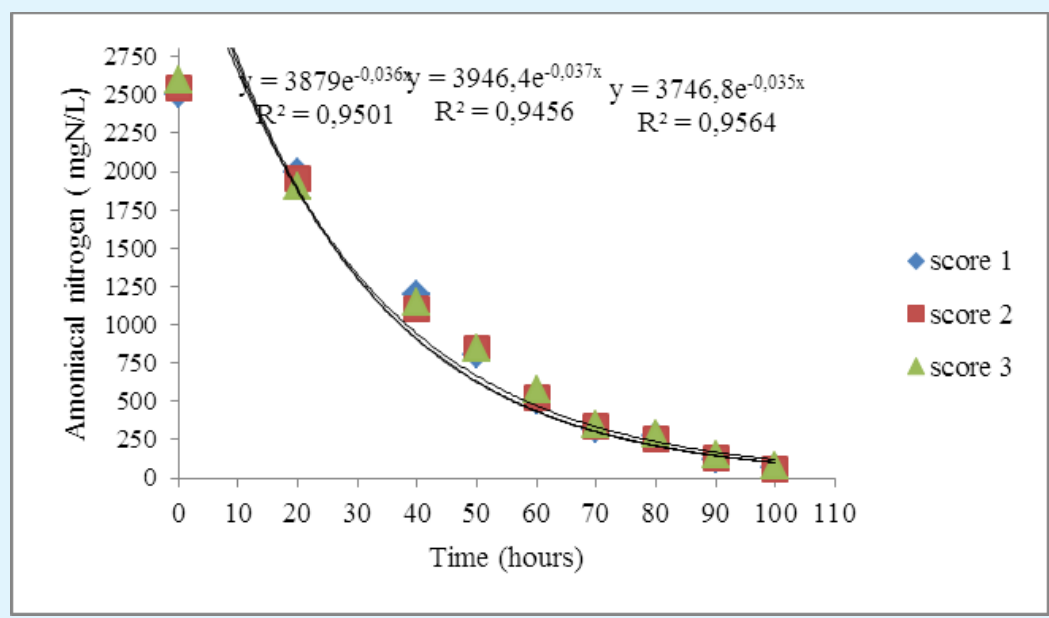

Figure 5: Behavior of temporal variations of ammoniacal nitrogen concentrations in experiment 2.

In this experiment, concentrations of ammoniacal nitrogen varied from $2,500.0$ to $2,600.0 \mathrm{mgN} / \mathrm{L}$ and were intensively reduced to a mean concentration of 80.0 $\mathrm{mgN} / \mathrm{L}$ after 100 hours of process monitoring, providing mean efficiency of $97.0 \%$, which is quite significant for ammonia stripping process performed with $\mathrm{pH}$ equal to 9.0. In this experiment, the $\mathrm{pH}$ of the "in natura" leachate was equal to 8.3 and was corrected to $\mathrm{pH} 9.0$ by adding sodium hydroxide $(\mathrm{NaOH}) \mathrm{PA}$ The amount of $\mathrm{NaOH}$ consumed for $\mathrm{pH}$ correction was $2.5 \mathrm{gNaOH} / \mathrm{L}$ of landfill leachate, impacting very little on the financial costs of the ammonia stripping process and favoring the cost / benefit ratio, since the effluent with ammoniacal nitrogen concentration 3.8 times lower when compared with the experiment 1 .

Comparing the operating time of the air stripping process as a function of the concentration of ammoniacal nitrogen, it can be verified that for landfill leachate with $\mathrm{PH}$ equal to $9 \mathrm{pH}$ units, the average rate of entrainment of ammoniacal nitrogen was of 3.6. 10-2 day-1. In the case of experiment 1 , where the $\mathrm{pH}$ of the landfill leachate was equal to $8.0 \mathrm{pH}$ unit, the mean drag rate constant was 2.1.10-2 day ${ }^{-1}$. Therefore, for the increment of only one $\mathrm{pH}$ unit, which was necessary to the addition of $2.5 \mathrm{~g} \mathrm{NaOH}$ (PA) per liter of landfill leachate and 100 hours air stripping process operation time performed in Jar Test equipment, the mean concentration of residual ammoniacal nitrogen was $80 \mathrm{mg} \mathrm{N} / \mathrm{L}$, which implies the reduction of environmental impacts of various natures and magnitudes and of public health.

\section{Conclusion}

- It can be verified that solid and liquid wastes generated by human and industrial activities hold significant concentrations of ammoniacal nitrogen, which can generate environmental impacts of different magnitudes in air, water and soil and also directly to humans. 


\section{Open Access Journal of Waste Management \& Xenobiotics}

- To reduce the concentration of ammoniacal nitrogen generated by human and industrial activities, it will be necessary to invest in the process of optimization of solid and liquid waste generation, with consequent treatment of these residues and the reuse of nutrients in priority agricultural activities.

- Ammonia gas is a potential source of environmental impacts and serious human health problems.

- The air stripping process can be applied to the separation of ammonia gas from the liquid phase to the gas phase. However, it is a direct function of the magnitude of the $\mathrm{pH}$, the faster the air stripping process will be performed. The operational question of working with high $\mathrm{pH}$ magnitudes is the consumption of alkaline and acidic chemical species, increasing the cost of the process.

- In this work, the efficiency of reduction of ammoniacal nitrogen concentration was $88.0 \%$ and $97.0 \%$ in experiments 1 and 2, respectively.

\section{References}

1. Abrelpe (2012) Associação Brasileira de Empresas de Limpeza Pública e Resíduos Especiais. Panorama de Resíduos Sólidos no Brasil, São Paulo: Abrelpe.

2. Renou S, Givaudan JG, Poulain S, Dirassouyan F, MOULIN P (2008) LandfillLeachateTreatment: Review and Opportunity. Journal of Hazardous Materials 150(3): 468-493.

3. Leite VD, Pearson HW, Sousa JT, LOPES WS (2011) The Removal of Ammonia from Sanitary Landfill Leachate Using a Series of Shallow Waste Stabilization Ponds.Water Science \& Technology 63(4): 666-670.
4. Moravia WG (2007) Estudos de caracterização, tratabilidade e condicionamento de lixiviados visando tratamento por lagoas, Digital Library-UFMG, pp: 161.

5. Salem Z, Hamouri K, Djemma R, Allia K (2008) Evaluation of landfill leachate pollution and treatment. Desalination 220(1-3): 108-114.

6. Abbas AA, Guo JS, Ping LZ, YA PY, Al-Rekabi WS (2009) Review on Landfill Leachate Treatments. American Journal of Applied Sciences 6(4): 672-684.

7. (2011) Brasil Conselho Nacional de Meio Ambiente. Dispõe sobre condições e padrões de lançamento de efluentes, complementa e altera a Resolução no 357, de 17 de março de 2005, do Conselho Nacional do Meio Ambiente-CONAMA. Resolução 430, de 13 de maio de.

8. Meulenbelt J (2007) Ammonia Medicine 35(11): 583584.

9. (2018) Ontario Ministry of the Environment. Ontario air Standards for ammonia. Ontario: Ontario Ministry of the Environment, Disponívelem, 2001: 52.

10. Metcalf \& Eddy (2003) Waste engineering: Treatment and reuse, $4^{\text {th }}$ (Edn.), Boston: McGraw-Hill.

11. Degermenci N, Ata ON, Yildiz E (2012) Ammonia removal by air stripping in a semi-batch jet loop reactor. Journal of Industrial and Engineering Chemistry 18(1): 399-404.

12. (2012) APHA-American Public Health Association. Standard Methods for the Examination of Water and Wastewater, 21 th (Edn.), Washington, DC: AmericanPublic Health Association. 